Schaefer, Arnold. 1885-87. Demosthenes und seine Zeit ${ }^{2} .3$ vols. Leipzig.

Schmitt, Oliver. 1992. Der Lamische Krieg. Bonn.

Spengel, Leonhard. 1851. Über die Rhetorik des Aristoteles. Munich.

, ed. 1867. Aristotelis Ars Rhetorica. Leipzig.

Stylianou, P. J., comm. 1998. A Historical Commentary on Diodorus Siculus, Book 15. Oxford.

Tataki, Argyro B. 1998. Macedonians Abroad: A Contribution to the Prosopography of Ancient Macedonia. Athens.

Trevett, Jeremy C. 1996. Aristotle's Knowledge of Athenian Oratory. CQ 46: 371-79.

Tuplin, Christopher J. 1979. Two Proper Names in the Text of Diodorus, Book 15. CQ 29: 347-57.

Walzer, Arthur E., and Brandon Inabinet. 2011. Who Wrote the Rhetoric? A Response to Brad

McAdon. Advances in the History of Rhetoric 14: 166-90.

Westlake, H. D. 1968. Individuals in Thucydides. Cambridge.

Whitehead, David, trans., comm. 2000. Hypereides: The Forensic Speeches. Oxford.

Worthington, Ian, trans., comm. 1992. A Historical Commentary on Dinarchus. Ann Arbor, MI.

- 2002. Who Is the Demosthenes at the End of Demosthenes 56, Against Dionysodorus?

An Exercise in Methodology. Scholia 11: 18-24.

—

. 2013. Demosthenes of Athens and the Fall of Classical Greece. Oxford.

2015. From East to West: Alexander and the Exiles Decree. In East and West in the World

Empire of Alexander: Essays in Honour of Brian Bosworth, ed. Pat Wheatley and Elizabeth

Baynham, 93-106. Oxford.

\title{
AMMIANUS, JULIAN, AND THE FATE OF GEORGE'S LIBRARY
}

Ecce autem repente perlato laetabili nuntio, indicante exstinctum Artemium, plebs omnis elata gaudio insperato, vocibus horrendis infrendens, Georgium petit, raptumque diversis mulcandi generibus proterens et conculcans, divaricatis pedibus, interfecit.

And behold, on the sudden arrival of the glad news disclosing the death of Artemius, the whole crowd, carried away by this unexpected joy, grinding their teeth and sounding terrible cries, made for George and seized him, abusing him in various ways and trampling upon him; then they dragged him about spread-eagle fashion, and killed him. (Trans. Rolfe, adapted)

-Ammianus 22.11.8

The historian Ammianus Marcellinus offered an account of the death of Bishop George, torn asunder by an Alexandrian mob, claiming at both 22.11.3 and 22.11.8 that it was predicated by the death of the notorious Artemius. The emperor Julian summoned Artemius to Antioch and had him executed in the suburb of Daphne in autumn 362, a date confirmed by Artemii passio 67. That later source, focusing on Artemius as a supposed Christian martyr, leaned heavily for details upon the roughly contemporary Ecclesiastical History of Philostorgius. This seems straightforward until one recalls that when Julian wrote to the Alexandrians to chide them for murdering George, he also mentioned in that same letter that Artemius was very much alive (Julian Ep. 60 To the Alexandrians 379ab). The Historia acephala, an account of ecclesiastical events focused on the career of Athanasius, resolves this by placing the murder of George in Alexandria on December 24, 361 (Historia acephala 8). This source, an account whose reliability "there is no reason to doubt," is local and offers detail beginning from George's imprisonment following the news of Constantius II's death on November 30, 
361. ${ }^{1}$ The passage in Ammianus is an example of his manipulation of historical events for literary and partisan purposes, in this case supporting Julian. The historian employed a subtle form of inductive argument by using Julian, "the undoubted focus of the Res Gestae," as an exemplum nineteen times in the Res Gestae. ${ }^{2}$ Ammianus' portrayal of Julian is a factor in a recent assessment of him as a writer displaying "the creative and imaginative powers of a novelist." "3ven Ammianus' description of George's end, rent asunder by an Alexandrian mob, is linked again to the news of the death of Artemius (Ammianus 22.11.8). It has been plausibly suggested that Ammianus deliberately relocated the murder of George from the inception of Julian's reign in order to minimize the damage to his reputation for tolerance this might cause in chronological conjunction with the siege of Aquileia and the Chalcedon trials. ${ }^{4}$ As one scholar notes, Ammianus' primary interest here is in highlighting his exemplar as the ideal righteous ruler. $^{5}$

Ammianus' tendentious claim not only obscured some problems for his exemplar Julian, it may have caused confusion among scribes and scholars regarding the date and place of two of the emperor's letters. At some time following the death of George, the emperor wrote to Alexandria demanding the library of George, who while bishop of Cappadocia had been in charge of Julian's education for a time, and lent him many books from his theological library (Julian Ep. 107 378c). Given the sizable corpus of the emperor's work, the epistles To Ecdicius $(E p .107 \mathrm{Bidez}=E p .23$ Wright $)$ and To Porphyrius $($ Ep. $106 \mathrm{Bidez}=$ Ep. 38 Wright $)$ do not exactly loom large, with his philosophical orations or anti-Christian writings usually taking precedence, and deservedly so. Despite their lack of recognition, these brief letters hold some unappreciated significance as the link to a shift in Julian's thinking.

Julian wrote To Ecdicius to the prefect of Egypt, a well-known government official with whom he corresponded fairly frequently. ${ }^{6}$ In it, the emperor demanded that George's library be found and sent to him, and made clear that he wanted included the works on the

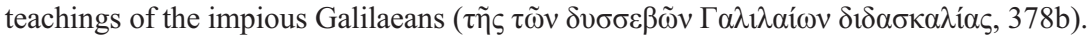
Even though he stated that he found them unworthy of survival, he demanded their inclusion on the rationale that related worthy works might be lost. The importance of this request is underlined by the mention that George's unnamed private secretary would be granted his freedom for delivering the library, and put to torture if he failed. To Porphyrius reiterated the same demand for the library, with Wilmer Wright, Joseph Bidez, and Franz Cumont theorizing that the addressee was perhaps George's secretary. If that assumption is correct, then given Porphyrius' affiliation with the detested George, it is unusual that the opprobrium directed at the writings of the Christians was excised from this letter. After all, Julian had publicly declared that although he disapproved of the Alexandrians taking the law into their own hands, he was pleased with the demise

1. Den Boeft et al. 1995, 202.

2. Ross 2016, 9; Kelly 2008, 258-59, 301.

3. Barnes 1998, 198. Even Matthews (1989, 443), who is much more positively inclined toward Ammianus, summarized his account of George's death as "historically invalid."

4. Sabbah 1978, 481-82; cf. Caltabiano 1986, 17-59; Den Boeft et al. 1995, 202; Fontaine et al. 1996, $316-17$.

5. Brennecke 1997, 238 .

6. Jones et al. 1971, 276. 


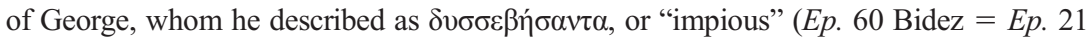
Wright To the Alexandrians 379c = Socrates Hist. eccl. 3.3.10). To this was added an incongruous है $\rho \omega \sigma o$, or "farewell," at the close of the letter (411d). The combination of all of the above suggests that something is amiss in the cheery signature to the letter, hinting at tampering or forgery. Bidez, Cumont, and Wright all held to scribal addition of the है $\rho \rho \omega \sigma o$, while Johannes Geffcken evidently suspected outright forgery of the letter. ${ }^{7}$

There is no consensus among modern scholars regarding the dating of the letters, but it is difficult to imagine both letters being authored in Constantinople in January 362, with Julian immediately requesting the library and then ordering it sent ahead unexamined to Antioch. Bidez and Cumont dated both To Porphyrius and To Ecdicius sometime after July 362, when Julian arrived in Antioch. ${ }^{8}$ This is the dominant view, due to Bidez having produced both the standard edition of Julian's letters and the most influential biography of the emperor as well. ${ }^{9}$ Nevertheless, there are problems with this dating. Bidez proposed a rather rigid chronology that depended upon Julian initially being "tolerant" and only gradually forced into confrontation, somewhat similar to his nowdiscredited intellectual evolution of Porphyry from superstitious to rational. ${ }^{10}$ As researching the pernicious writings of the Galilaeans with an eye to engaging them would not have been needed in a "tolerant" period, this necessarily shunts these letters into a later period chronologically. However, if both are dated to Julian's Antioch period, post-July 362, why wait so long after George's death in December 361, almost ensuring that the library would be dispersed? Wright suggested an alternate solution, namely that To Ecdicius was authored in January 362 and To Porphyrius in July 362, with the second letter following because the first failed to produce results. ${ }^{11}$ This seems an improvement, although one that could conceivably have cost Ecdicius his post as Prefect of Egypt, which we know he kept until after Julian's death in 363. Indeed, Julian sent Ecdicius other letters in this period that contained no reminder of the missing library (Epp. 108, 109, 112 Bidez $=$ Epp. 45, 49, 46 Wright).

I should like to propose a solution that relies on the hypothesis that Julian did indeed receive George's library, which resulted in a sharp increase in his theological acumen. This demand for the library ties into Julian's interest in using Christian theology against the church in his Oration 7 To the Cynic Heracleios that spring, where he abruptly shifted his focus from mocking the church to co-opting Christian theology to use against the church, a component of that work that was not fully appreciated in Bidez's day. Bidez and Cumont connected the arrival of George's theological library to Julian's production of his Against the Galilaeans, frequently perceived as Julian's first real engagement of Christian theology. But was it? While modern scholars may articulate the focus of the work differently, many realize that with it, a significant shift takes place. Maria Carmen De Vita points out that this work marks the transition to a phase of religious and philosophical works, and similarly, another scholar assessed it as his "first

7. Bidez and Cumont 1922, 165; Wright 1923, 124-25; Geffcken 1914, 163.

8. Bidez and Cumont 1922, 164.

9. Bidez and Cumont 1922 and Bidez [1930] 1965, respectively. Caltabiano (1991, 204-5) and Elm (2012, 301-2) date both letters to summer 362 .

10. Bidez [1930] 1965, 227-28, 263-66, 286-89; [1913] 1964, 18-19, 25-28; refuted by, e.g., Smith (1987, $722-23$ ) and others since.

11. Wright $1923,123$. 
explicit criticism of Christian teachings."12 Klaus Rosen describes Julian's work as the unveiling of his religious state program, while other recent research into Julian's Oration 7 has highlighted Julian's crafting of a Christ-like Heracles, the son of Zeus-Helios and the virgin goddess Athena, his crafting of a parallel Heraclean role for himself, also the son of Zeus-Helios and Athena, and his appropriation for himself of the account of Christ's temptation in the wilderness. ${ }^{13}$ This development in theological interest came rather suddenly, and well fits the acquisition of a theological library with which the emperor was already familiar. Even if George's library had not arrived in time to form the basis for Julian's Oration 7, the composition of that work explains his interest in acquiring Christian theological writings.

In this reconstruction, Julian wrote To Ecdicius shortly after the murder of George in December 361, the most logical time for at least one of the letters to be written. Given the lack of support in several regards, I suggest that To Porphyrius is either a forgery or at the least contains scribal errors that mitigate against its use in reliably dating $T o$ Ecdicius. The delivery of the library requested in To Ecdicius equipped Julian to ramp up his engagement of the church by composing a work, Oration 7 To the Cynic Heracleios, that used Christian theology against it.

DAVId NeAL GREENWOOD University of Aberdeen

12. De Vita $(2015,119)$ writes, "Or. 7 Contro il Cinico Eraclio occupa un posto tutto particolare, di transizione - si potrebbe dire - dai discorsi di carattere squisitamente retorico-encomiastico a quelli di carattere filosofico-religioso." Cf. Elm 2012, 111.

13. Rosen 2006, 57; Greenwood 2014a; 2014b.

\section{LITERATURE CITED}

Barnes, Timothy D. 1998. Ammianus Marcellinus and the Representation of Historical Reality. Ithaca, NY.

Bidez, Joseph. [1913] 1964. Vie de Porphyre: Le Philosophe Néo-Platonicien. Hildesheim. . [1930] 1965. La vie de l'empereur Julien ${ }^{3}$. Paris.

Bidez, Joseph, and Franz Cumont, eds. 1922. Iuliani epistulae leges poemata fragmenta varia. Oxford.

Brennecke, Hanns C. 1997. Christliche Quellen des Ammianus Marcellinus? ZAC 1: 226-50.

Caltabiano, Matilde. 1986. L'assassino di Georgio di Cappadocia. Quaderni catanesi di storia 7: 17-59.

- ed. 1991. L'epistolario di Giuliano imperatore. Naples.

den Boeft, J., J. W. Drijvers, D. den Hengst, and H. C. Teitler, eds. 1995. Philological and Historical Commentary on Ammianus Marcellinus XXII. Leiden.

De Vita, Maria Carmen. 2015. Giuliano e l'arte della "nobile manzogna" (Or. 7, Contro il Cinico Eraclio). In L'Imperatore Giuliano: Realtà storica e rappresentazione, ed. Arnaldo Marcone, 119-48. Milan.

Elm, Susanna. 2012. Sons of Hellenism, Fathers of the Church: Emperor Julian, Gregory of Nazianzus, and the Vision of Rome. Berkeley, CA.

Fontaine, Jacques, E. Frézouls, and J. D. Berger, eds. 1996. Ammien Marcellin, Histoires Livres $X X-X X I I$. Paris.

Geffcken, Johannes. 1914. Kaiser Julianus. Leipzig.

Greenwood, David Neal. 2014a. Crafting Divine Personae in Julian's Oration 7. CP 109: 140-49. 
2014b. A Pagan Emperor's Appropriation of Matthew's Gospel. Expositorv Times 125: 593-98.

Jones, A. H. M., J. R. Martindale, and J. Morris. 1971. The Prosopography of the Later Roman Empire. Vol. 1. Cambridge.

Kelly, Gavin. 2008. Ammianus Marcellinus: The Allusive Historian. Cambridge.

Matthews, John F. 1989. The Roman Empire of Ammianus. London.

Rolfe, John C., trans. 1940. Ammianus Marcellinus: "History." Vol. 2, Books 20-26. Loeb Classical Library. Cambridge, MA.

Rosen, Klaus. 2006. Julian: Kaiser, Gott und Christenhasser. Stuttgart.

Ross, Alan. 2016. Ammianus' Julian: Narrative and Genre in the "Res Gestae." Oxford.

Sabbah, Guy. 1978. La méthode d'Ammien Marcellin: Recherches sur la construction du discours historique dans les "Res Gestae." Paris.

Smith, Andrew. 1987. Porphyrian Studies since 1913. In ANRW II.36.2: 717-73.

Wright, Wilmer C. F., ed., trans. 1923. The Works of the Emperor Julian. Vol. 3. London. 